\title{
Uptake of health care services and health status of HIV-infected women diagnosed through antenatal HIV screening in Barbados, 1996-2004
}

\author{
Alok Kumar, ${ }^{1}$ Krishna R. Kilaru, ${ }^{2}$ Sheila Forde, ${ }^{2}$ and Ira Waterman ${ }^{2}$
}

Suggested citation $\quad \begin{aligned} & \text { Kumar A, Kilaru KR, Forde S, Waterman I. Uptake of health care services and health status of HIV- } \\ & \text { infected women diagnosed through antenatal HIV screening in Barbados, 1996-2004. Rev Panam Salud }\end{aligned}$ infected women diagnosed

ABSTRACT Objectives. To study utilization of HIV-related health care services and to describe the health status of HIV-infected women diagnosed through antenatal voluntary counseling and testing (VCT) for HIV infection in Barbados.

Methods. This is a descriptive study. The study population includes all HIV-infected women in Barbados diagnosed as HIV-infected through VCT for HIV infection during 1996-2004.

Results. The median duration of HIV infection from time of diagnosis to the time of this report for the 163 women diagnosed during the study period was 72 months (low range, 9 months; high range, 117 months). Of the 163 women, 102 (62.6\%) had attended the centralized HIV/AIDS clinic for follow-up (care, treatment, and monitoring), whereas $61(37.4 \%)$ had never attended the clinic. The median time lag between diagnosis of HIV infection and first presentation to the HIV/AIDS clinic was 36 months (low range, 1 month; high range, 114 months). Of the HIV-infected women who attended the HIV/AIDS clinic, more than onefourth had severe immunodeficiency at the time of their first follow-up visit. Of the 53 women undergoing highly active anti-retroviral therapy (HAART) at the time of the study, 23 $(43.4 \%)$ began the therapy within three months of their first follow-up visit.

Conclusions. Early HIV diagnosis through antenatal VCT is not enough to ensure that women with HIV will get adequate and timely HIV-related health care. These women suffer significant premature mortality, largely related to inadequate follow-up.

Key words HIV infections, pregnant women, health status, Barbados.

Lecturer, School of Clinical Medicine and Research, The University of the West Indies (Cave Hill), and Associate Consultant, The Queen Elizabeth Hospital, Bridgetown, Barbados. Send correspondence and requests for reprints to: Alok Kumar, School of Clinical Medicine and Research, The University of the West Indies, Cave Hill Campus University Drive, Cave Hill, St. Michael, Bridgetown, Barbados, West Indies; telephone: (246) 436-6450; fax: (246) 429 5374; e-mail: alokkumar.uwichill@gmail. com

2 Ladymeade HIV/AIDS Reference Unit, Ministry of Health, Bridgetown, Barbados.
Realizing the full potential benefits of antenatal voluntary counseling and testing (VCT) for HIV infection is both an economic compulsion and a necessary public health objective for any successful and viable HIV/AIDS prevention program (1-4). Antenatal testing is undertaken primarily to offer interventions for prevention of mother- to-child transmission (PMTCT) of HIV. However, the HIV diagnosis has implications for the mother herself, which is often forgotten. Many, including the mothers themselves, wonder about the significance of the letter " $\mathrm{M}$ " in "PMTCT" programs, given the way such programs are implemented in developing countries. This is particularly 
disturbing in the era of highly active anti-retroviral therapy (HAART), given that model-based estimates indicate identifying patients early through antenatal screening, rather than through case finding, and beginning therapy when the CD4 count ${ }^{3}$ is 350 cells $/ \mu \mathrm{L}$, rather than waiting until values drop to less than 200 cells $/ \mu \mathrm{L}$, resulted in a survival advantage $(5,6)$. Equally troublesome is developing countries' tendency to advocate support for home care, community programs, and government services as effective responses to the global orphan tragedy (7) without addressing the cause, that is, preventing the creation of orphans by developing strategies to save the lives of parents.

Since 1996, more than four-fifths of pregnant women in Barbados have received VCT for HIV infection during antenatal care (8). In 2002, the national Mother-to-Child Transmission Plus (MTCT-Plus) initiative was established to meet the needs of every family member infected or affected by HIV/AIDS. Before that time, programs to prevent mother-to-child transmission of HIV did not provide care and treatment to HIV-infected pregnant women and mothers. To fill this gap, the MTCT-Plus initiative expanded PMTCT programs to include comprehensive treatment services for pregnant and postpartum women. Nevertheless, the question remains whether the full benefits of VCT are being realized in terms of making a difference in the health of HIVinfected women. To answer this question, this study analyzed the use of HIV-related follow-up health services (care, treatment, and monitoring) by postpartum HIV-infected women, and their health status at first followup visit after the delivery of their babies.

\footnotetext{
3 CD4 cell count is a marker of the degree of immunodeficiency in persons infected with HIV. Normal CD4 cell count is usually greater than 750 cells $/ \mu L$. Values less than 200 cells $/ \mu \mathrm{L}$ are considered to represent severe immunodeficiency.
}

\section{MATERIALS AND METHODS}

\section{Study population}

This is a descriptive study. The study population includes all HIVinfected women in Barbados diagnosed through antenatal VCT for HIV infection from January 1996 through December 2004. The study participants, like all new mothers in Barbados diagnosed with HIV, and their newborns, are enrolled in the Pediatric HIV Surveillance Program provided through national public health care services.

Barbados has a well-organized antenatal care delivery system delivered through three main types of health care facilities: state-run polyclinicsnational primary care facilities where most pregnant women receive their antenatal care; private offices of obstetricians and general practitioners; and The Queen Elizabeth Hospital (QEH) in Bridgetown, Barbados' tertiary care referral hospital. Both the polyclinics and private doctors' offices liaise closely with QEH, where most deliveries are carried out. Following delivery, most women return to their respective polyclinics for postnatal follow-up, while others receive follow-up at the private obstetrician or general practitioner's office where they received antenatal care. HIV-exposed newborns are followed up at the QEH Pediatric Clinic, whereas HIV-infected mothers are referred to the centralized HIV/ AIDS clinic run by the Ministry of Health $(\mathrm{MOH})$. Established in the early 1990s for the sole purpose of providing continuous follow-up to all HIV-infected persons in the country, the clinic was located at the QEH Respiratory Unit (RU) until 2002, when it was moved to its current location at the Ladymeade Reference Unit (LRU) at $\mathrm{MOH}$ facilities in Bridgetown.

Follow-up of HIV-infected women involves monitoring their general health; conducting CD4 cell counts; and providing prophylaxis, as well as treatment of opportunistic infections. Since 2001, HAART (highly active anti-retroviral therapy) has been provided for all HIV-infected persons in
Barbados; the therapy is provided free of cost at the point of delivery, based on U.S. Department of Health and Human Services (DHHS) guidelines modified for the Caribbean. A CD4 cell count of less than 200 cells $/ \mu \mathrm{L}$ is an absolute indication for commencing HAART. Some persons with a CD4 cell count between 200 and 350 cells $/ \mu \mathrm{L}$ are also treated, based on their clinical stage and/or viral load level.

\section{Study ethics}

All HIV-infected women who delivered from 1996 through 2004 were identified from the Pediatric HIV Surveillance Program database. The women were contacted, and informed consent for the study was obtained. Study participants were assured of the complete confidentiality of all information provided for the purpose of the study. They were also assured that their information would in no way influence their ongoing HIV/AIDS care or future medical care. The study method was approved by the Institutional Review Board for ethical issues in research at The University of the West Indies (Cave Hill) School of Clinical Medicine and Research in Barbados.

\section{Data collection methodology}

Information on study participants' demographic data, including age, employment status, living arrangements, and marital status, was collected from records of their antenatal care maintained at the QEH. Information on their use of HIV-related health services and the status of their health with respect to HIV / AIDS-related illness, including time and year of diagnosis and admission, and outcome, at the QEH; followup at the HIV/AIDS clinic at the QEH RU (before 2002) or the LRU (after 2002); treatment, and adherence to treatment (if any); and deaths (if any) was collected from LRU and QEH medical records. For women who received follow-up at the HIV/AIDS clinic at $R U / L R U$, information on their first 
presentation at the clinic, their health status at the time, and their CD4 counts was collected from records maintained at the LRU.

\section{Outcome measures and statistical methods}

Outcome measures included proportion of study participants attending the RU/LRU for HIV / AIDS-related illness, time interval between HIV diagnosis and first visit to the RU/LRU, CD4 cell counts at first visit to the RU/LRU, proportion of study participants on HAART, time interval between first presentation to the RU/LRU and initiation of HAART, compliance with follow-up, and mortality.

All data collected for the study were stored in a pre-designed Microsoft Access database and analyzed using SPSS statistical software package, version 11. The 9-year study period was further divided, based on the availability of HAART, into three 3-year sub-periods: 1996-1998, 1999-2001, and 2002-2004. For the purpose of comparison, the 1996-1998 period, when no antiviral therapy was available for treatment of HIV-infected persons in the country, was selected as a baseline and compared with the 2002-2004 period, when HAART was available for treatment. Antiretroviral therapy (mostly dual therapy) was also available during the 1999-2001 period, but only for a few HIVinfected individuals. The $95 \%$ confidence interval (CI) was corrected for continuity. Chi-square tests were used to analyze proportional data, and a $p$ value $\leq 0.05$ was considered statistically significant. Graphs were prepared with Microsoft Excel for Windows $X P$, version 7.0.

\section{RESULTS}

\section{Socio-demographic profile of study population}

During the study period, 163 HIVinfected women were diagnosed for the first time through antenatal screening. Table 1 shows the relevant sociodemographic profile of these women. Most of them were in the 21-30 age group $(56.4 \%)$, single $(80.4 \%)$, and unemployed $(42.3 \%) ; 151$ (92.6\%, 95\% $\mathrm{CI}=87.2 \%, 95.9 \%)$ were asymptomatic at the time of their diagnosis. Twentyfour $(14.7 \%, 95 \% \mathrm{CI}=9.8 \%, 21.3 \%)$ women were deceased, and the whereabouts and status of $5(3.1 \%, 95 \% \mathrm{CI}=$ $1.3 \%, 6.9 \%$ ) were unknown. The remaining $134(82.2 \%, 95 \% \mathrm{CI}=75.6 \%$, $87.3 \%$ ) were alive at the time of the study (Table 2). The median duration of HIV infection from the time of diagnosis up to the time of this study was 72 months (low range, 9 months; high range, 117 months). Sixty-eight (41.7\%, $95 \%$ CI $=34.4 \%, 49.4 \%$ ) women were diagnosed during the period 1996$1998,58(35.6 \%, 95 \% \mathrm{CI}=28.6 \%, 43.2 \%)$ were diagnosed during 1999-2001, and $37(22.7 \%, 95 \%$ CI $=16.9 \%, 29.7 \%)$ were diagnosed during 2002- 2004 (Table 3).

\section{Follow-up of women diagnosed through antenatal VCT as HIV- infected}

As shown in Table 2, of the 163 women diagnosed as HIV-infected through antenatal screening, 102 $(62.6 \%, 95 \% \mathrm{CI}=54.9 \%, 69.6 \%)$ had attended the centralized HIV / AIDS clinic (RU/LRU) - the only clinic for complete and comprehensive follow-up (care, treatment, and monitoring) of HIV-infected persons in Barbados-and $61(37.4 \%, 95 \% \mathrm{CI}=30.0 \%, 45.3 \%)$ had never attended the clinic for follow-up. For the $102 \mathrm{HIV}$-infected women who had attended the centralized HIV/ AIDS clinic, the median time interval between diagnosis of HIV infection and first presentation to the clinic for followup was 36 months (low range, 1 month; high range, 114 months).

\section{Health status of HIV-infected women at first follow-up visit}

More than one-fourth $(28.4 \%, 95 \%$ $\mathrm{CI}=20.1 \%, 38.4 \%)$ of those who pre-
TABLE 1. Socio-demographic profile of 163 HIV-infected women diagnosed through antenatal screening

\begin{tabular}{lrr}
\hline \multicolumn{1}{c}{ Characteristic } & $n$ & $(\%)$ \\
\hline Age (years) & & \\
$\leq 20$ & 43 & 26.4 \\
$21-30$ & 92 & 56.4 \\
$31-40$ & 27 & 16.6 \\
$>40$ & 1 & 0.6 \\
Marital status & 131 & 80.4 \\
$\quad$ Single & 32 & 19.6 \\
Married & & \\
Employment status & 69 & 42.3 \\
$\quad$ Unemployed & 94 & 57.7 \\
Employed & & \\
Disease status at time of & & \\
$\quad$ diagnosis & 151 & 92.6 \\
Asymptomatic & 12 & 7.4 \\
Symptomatic & & \\
Time since diagnosis of & & \\
$\quad$ HIV infection & 35 & 21.5 \\
1-3 years & 46 & 28.2 \\
4-6 years & 82 & 50.3 \\
7-9 years & & \\
\hline$\quad$ & & \\
\hline
\end{tabular}

TABLE 2. Follow-up and health status of 163 HIV-infected women diagnosed through antenatal screening

\begin{tabular}{|c|c|c|}
\hline Follow-up/health status & $n$ & (\%) \\
\hline \multicolumn{3}{|c|}{$\begin{array}{l}\text { Attendance at HIV/AIDS } \\
\quad \text { clinic for care and treatment }\end{array}$} \\
\hline Attended & 102 & 62.6 \\
\hline Never attended & 61 & 37.4 \\
\hline Total & 163 & \\
\hline \multicolumn{3}{|l|}{ Current status } \\
\hline Living & 134 & 82.2 \\
\hline Deceased & 24 & 14.7 \\
\hline Unknown & 5 & 3.1 \\
\hline Total & 163 & \\
\hline \multicolumn{3}{|c|}{$\begin{array}{l}\text { CD4 cell count at time of } \\
\text { first presentation to RU/LRU }\end{array}$} \\
\hline$<200 / \mu \mathrm{L}$ & 29 & 28.4 \\
\hline $200-499 / \mu \mathrm{L}$ & 43 & 42.2 \\
\hline$\geq 500 / \mu \mathrm{L}$ & 28 & 27.4 \\
\hline Unavailable & 2 & 2.0 \\
\hline Total & 102 & \\
\hline \multicolumn{3}{|c|}{ Health status at first follow-up visit } \\
\hline Satisfactory & 79 & 77.5 \\
\hline Poor & 23 & 22.5 \\
\hline Total & 102 & \\
\hline \multicolumn{3}{|l|}{ Antiretroviral therapy } \\
\hline On HAART & 53 & 52.0 \\
\hline Not on HAART & 49 & 48.0 \\
\hline Total & 102 & \\
\hline \multicolumn{3}{|l|}{ Adherence to HAART } \\
\hline Good & 43 & 81.1 \\
\hline Poor & 10 & 18.9 \\
\hline Total & 53 & \\
\hline
\end{tabular}


TABLE 3. Trends in uptake of health care services for 163 women diagnosed as HIV-infected during three sub-periods, 1996-2004

\begin{tabular}{|c|c|c|c|c|c|c|}
\hline & \multicolumn{2}{|c|}{ 1996-1998 } & \multicolumn{2}{|c|}{ 1999-2001 } & \multicolumn{2}{|c|}{ 2002-2004 } \\
\hline & $n$ & $(\%)$ & $n$ & $(\%)$ & $n$ & $(\%)$ \\
\hline $\begin{array}{l}\text { Number of women diagnosed } \\
\text { as HIV-infected }\end{array}$ & 68 & 41.7 & 58 & 35.6 & 37 & 22.7 \\
\hline $\begin{array}{l}\text { Status at time of study } \\
\text { Deceased } \\
\text { Alive } \\
\text { Unknown }\end{array}$ & $\begin{array}{r}13 \\
53 \\
2\end{array}$ & $\begin{array}{c}19.1 \\
77.9 \\
3.0\end{array}$ & $\begin{array}{r}9 \\
46 \\
3\end{array}$ & $\begin{array}{r}15.5 \\
79.3 \\
5.2\end{array}$ & $\begin{array}{r}2 \\
35 \\
0\end{array}$ & $\begin{array}{r}5.4 \\
94.6 \\
0.0\end{array}$ \\
\hline $\begin{array}{l}\text { Follow-up at LRU/RU } \\
\text { Did not receive } \\
\text { Received }\end{array}$ & $\begin{array}{l}30 \\
38\end{array}$ & $\begin{array}{l}44.1 \\
55.9\end{array}$ & $\begin{array}{l}23 \\
35\end{array}$ & $\begin{array}{l}39.7 \\
60.3\end{array}$ & $\begin{array}{r}8 \\
29\end{array}$ & $\begin{array}{l}21.6 \\
78.4\end{array}$ \\
\hline $\begin{array}{l}\text { Quality of adherence to follow-up schedules } \\
\text { by those who received services } \\
\text { Good (attended at least once every } 3 \text { months) } \\
\text { Poor (lost to system or attended less than } \\
\text { once every } 3 \text { months) }\end{array}$ & 19 & 50.0 & 23 & 65.7 & 21 & 72.4 \\
\hline $\begin{array}{l}\text { Treatment status of women with good } \\
\text { adherence to follow-up at time of study } \\
\text { Not on HAART } \\
\text { On HAART }\end{array}$ & $\begin{array}{r}7 \\
12\end{array}$ & $\begin{array}{l}36.8 \\
63.2\end{array}$ & $\begin{array}{l}11 \\
12\end{array}$ & $\begin{array}{l}47.8 \\
52.2\end{array}$ & $\begin{array}{r}14 \\
7\end{array}$ & $\begin{array}{l}66.7 \\
33.3\end{array}$ \\
\hline
\end{tabular}

sented for follow-up and had a CD4 cell count done at the time of their first presentation to the RU/LRU had severe immunodeficiency (CD4 cell counts $<200 / \mu \mathrm{L})$ (Table 2). Of the 102 women who attended the follow-up clinic, $53(52.0 \%, 95 \% \mathrm{CI}=41.9 \%$, 61.9\%) were undergoing HAART up to the time of this study. Of those who received HAART, $23(43.4 \%, 95 \% \mathrm{CI}=$ $30.1 \%, 57.6 \%$ ) had begun the therapy within three months of their first follow-up visit. Adherence to HAART was reported as good (taking more than or equal to $96 \%$ of their prescribed medicine) in over four-fifths (43, or $81.1 \%$ ) of those receiving the therapy. Among the 102 study participants attending the follow-up clinic, adherence to follow-up schedules was considered good (attended the clinic at least once every three months after their initial visit) for $63(61.8 \%)$ women and poor (lost to follow-up or presented for follow-up less frequently than once every three months) in the case of $39(38.2 \%)$ women (Table 3).

\section{Trends in uptake of health care services and health status of HIV-infected women}

Trends in accessing HIV-related (follow-up) health services by the 163 HIV-infected women diagnosed through antenatal screening, and their health status, are shown in Table 3. Of those diagnosed as HIV-infected during the 1996-1998 period, $55.9 \%$ had attended the centralized HIV/AIDS clinic (RU/LRU) at some point; the corresponding figure for 2002-2004 increased to $78.4 \%$ (chi-square tests for trend; $p=0.049$ ). Only 50\% of HIVinfected women diagnosed during 1996-1998 who attended the centralized HIV/AIDS clinic for follow-up services had good adherence to follow-up schedules (at least once every three months), while the corresponding figure for 2002-2004 increased to $72.4 \%$ (chi-square tests for trend; $p=0.034$ ).

For HIV-infected women who presented for follow-up at the centralized HIV/AIDS care clinic, the median time interval between diagnosis of HIV infection and first presentation to the follow-up clinic dropped from 53 months during 1996-1998 to 4 months during 2002-2004 (Figure 1). The proportion of all HIV-infected women attending the RU/LRU who presented for follow-up within six months of their diagnosis of HIV infection increased from $21 \%$ during 1996-1998 to $67 \%$ during 2002-2004 ( $p<0.0001)$. During 1996-1998, 32\% of all HIVinfected women who presented for follow-up and underwent a CD4 cell count had values of less than $200 / \mu \mathrm{L}$; this figure decreased to $14 \%$ during 2002-2004 ( $p=0.048)$.

\section{DISCUSSION}

Barbados is one of the smaller countries in the English-speaking Caribbean, with an estimated 2001 population of 266,800 and a per capita gross national product of US\$ 18200 (2006). The estimated (crude) mortality rate for Barbados for 2001 was 8.3 per 1000 population (9), and the adult prevalence rate of HIV in the country is estimated at $1.75 \%$, with a male-to-female ratio of 2:1 (10). The Government of Barbados views health care as a fundamental right of all Barbadians and aims to provide comprehensive health care to all its citizens through its elaborate government-controlled health care system, free of cost at the point of delivery. Since the early 1990s, a number of interventions were targeted to reduce mother-to-child transmission of HIV in the country. These included the provision of free antenatal VCT (voluntary counseling and testing) for HIV infection since 1991 and free antiretroviral drugs for perinatal prophylaxis since 1996, resulting in a dramatic decline in the rate of perinatal transmission of HIV in the country (11). These measures were followed up by the provision of free antiretroviral treatment for all eligible HIV-infected individuals in the country since 2002, coupled with HIV/AIDS education interventions targeting the general public. All potential benefits of VCT must 
FIGURE 1. Trends in delay in seeking follow-up care by 163 HIV-positive women diagnosed through antenatal screening in Barbados during 1996-2004

Median time period (months) between diagnosis and first follow-up visit

Proportion of women presenting for follow-up within 6 months of HIV diagnosis

Proportion of women with CD4 cell count $<200 / \mu \mathrm{L}$ at first follow-up visit

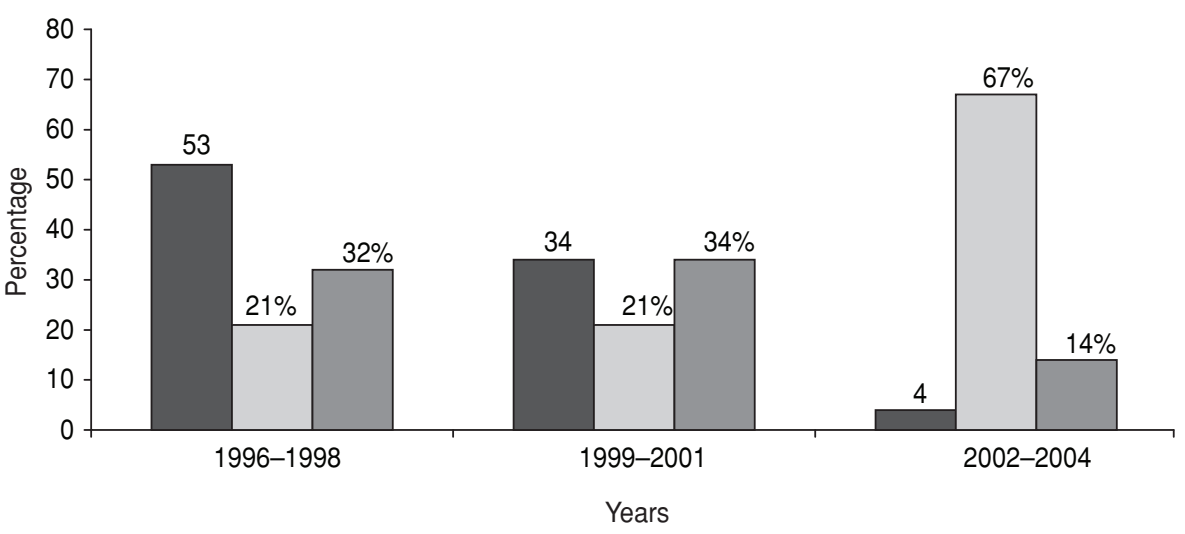

be realized in order for it to be a costeffective and powerful tool in the fight against the spread of HIV / AIDS. Early detection of HIV infection in childbearing women through antenatal screening following VCT is an important tool with huge potential benefits, especially when coupled with the provision of HAART $(6,7)$. The findings of this study are therefore relevant, and important, particularly in view of the lack of any other published reports on these types of studies from the Caribbean region.

\section{Delayed follow-up of HIV-infected women}

The socio-demographic profile of the HIV-infected women in this study was consistent with those of the authors' earlier report, which described the socio-demographic profile of HIVinfected postpartum women in Barbados (12). It should be noted that more than 40 percent of the women under study had been diagnosed with HIV for 6 to 9 years, while the HIV status of more than four-fifths had been known for more than 3 years. Keeping these figures in mind, it is a cause of great concern that more than one-third of the 163 women diagnosed through antenatal screening as HIV-infected after ized HIV / AIDS clinic at the RU/LRU, which was designed to serve as a "one-stop shopping center" for persons affected by HIV/AIDS. Equally worrisome was the fact that entry into the follow-up system for those who did seek HIV-related care and treatment was significantly delayed (with a median time lag of 16 months between diagnosis of HIV infection and first presentation to follow-up clinic). This suggests the loss of much of the potential advantage gained through early diagnosis during the antenatal period following VCT. More than one-third of those who sought follow-up had poor adherence to it or were lost to the follow-up system altogether. Loss to follow-up, significantly long delays in seeking follow-up (following HIV diagnosis), and failure to comply with follow-up schedules are serious challenges to Barbados' MTCT-Plus initiative. The findings from this study reinVCT had never attended the central- force observations made in other studies from developing countries (13-15).

\section{The HAART factor}

There are two interesting findings in regard to HAART and HIV-infected women diagnosed through antenatal screening. First, the unavailability of HAART during the initial (1996-2001) part of the study period could have been partly responsible for the reluctance on the part of these women to access health care services. It should be noted, however, that most of these women were asymptomatic at the time of their diagnosis and therefore would not have needed HAART until much later in the course of the disease. A second and somewhat troublesome finding is that even during the sub-periods when HAART was available, late presentation at advanced stage of the disease was reflected in a high percentage of women, most of whom were young (nearly three-fourths under 30) and asymptomatic (more than $90 \%$ ) at the time of diagnosis. By the time most of these women made their first visit to the centralized HIV/AIDS clinic (RU/LRU), they had CD4 cell counts of less than $200 / \mu \mathrm{L}$; therefore, most were started on HAART within three months of their first presentation. Given the evidence for poor outcome for HAART when initiated in patients with CD4 cell counts of less than $200 / \mu \mathrm{L}$ (16-19), these numbers indicate a failure to capitalize on early diagnosis of HIV infection in women who have willingly undergone HIV screening during antenatal VCT. They also imply the failure to prevent the orphaning of many of the infants born to these women, among whom HIV infection has been avoided through the use of perinatal ZDV/NVP4 prophylaxis (11). This suggests that the un-

\footnotetext{
4 St. John MA, Kumar A, Cave C, Carmichael K. Efficacy of nevirapine administration on the mother to child transmission of HIV using a modified HIVNET 012 regimen. [Conference presentation]. At: Caribbean Health Research Council 48th Annual Scientific Meeting, Nassau, Bahamas, 1-3 May 2003.
} 
availability of HAART for the major part of the study period (1996-2001) may have been a major limitation of the MTCT-Plus initiative as well as a reason for delayed access of services for HIV follow-up by HIV-infected women in Barbados.

\section{Role of stigma and discrimination}

Despite the provision of HAART free of cost, there has been a poor return on follow-up of HIV-infected women diagnosed through antenatal VCT. This could be an indicator of the high degree of HIV/AIDS-associated stigma and discrimination prevalent among this population; whether real, or perceived, or both, stigma and discrimination may be the biggest hurdle to the uptake of care and treatment services by HIV-infected women. A high prevalence of HIV/AIDS-associated stigma and discrimination associated with a low rate of self disclosure of HIV serostatus has been reported in previous studies of this population $(20,21)$. Until very recently, as in other parts of the developing world, HIV/AIDS-associated stigma and discrimination did not receive enough attention in Barbados.

\section{Trends and future outlook for the VCT program}

In analyzing trends in HIV-related follow-up services and their uptake by women in the study, it is heartening to note that both the median time interval between diagnosis and first follow-up visit and the proportion of women with a CD4 cell count less than $200 / \mu \mathrm{L}$ declined significantly during 2002-2004 compared to 1996-1998. These results should be viewed with caution, however, for even during 2002-2004 (when HAART was available free of cost for all HIV-infected persons in the country), more than one-fifth $(21.6 \%)$ of HIV-infected women diagnosed through antenatal screening during this period never attended the centralized HIV/AIDS clinic for follow-up, and more than one-seventh (14\%) of those who did eventually seek follow-up had a CD4 cell count less than $200 / \mu L$.

\section{CONCLUSIONS AND RECOMMENDATIONS}

During the follow-up period, which ranged from one to nine years, there was a significant level of mortality among the HIV-infected women diagnosed through antenatal VCT. This was associated with inadequate adherence to follow-up, or delayed seeking of follow-up (until relatively advanced stages of the disease), in many cases compounded by the unavailability of HAART during most of the study period. This indicates that HIV diagnosis alone is not enough to ensure that all women with HIV will receive adequate and timely health care. One constraint may be the fragmented structure of the present system for postnatal follow-up of HIV-infected women and their exposed newborns. In this system, the mother receives her postnatal follow- up at the clinic where she received antenatal care, but is referred to the centralized HIV / AIDS clinic for her HIV follow-up, while her baby receives follow-up at the QEH. This system of fragmented health care delivery, which requires visits to different health clinics located in different parts of the island, could have hampered study participants' follow-up.

Counseling and testing recommendations should highlight the intrinsic value of early diagnosis. Ongoing counseling from different members of the health care team involved in the care and treatment of these women, with frequent reinforcement and without stigmatization or discrimination, may increase the uptake of HIVspecific health care services by this population. Integrating antenatal and HIV/AIDS care for these women and their HIV-exposed infants in one clinic would add continuity and could thus strengthen the rapport between the HIV-infected women and their care provider. It may also improve adherence to and the quality of their followup. Conducting focus group discussions with these women to gain further insight into barriers to followup as perceived by these women may be useful in identifying system constraints as well as more appropriate and effective solutions.

Acknowledgement. This study was supported by a research grant for 2005 from the Caribbean Health Research Council, Port of Spain, The Republic of Trinidad and Tobago.

\section{REFERENCES}

1. Newell ML, Dabis F, Tolley K, Whynes D. Cost-effectiveness and cost-benefit in the prevention of mother-to-child transmission of HIV in developing countries. AIDS. 1998; 12:1571-80.

2. Marseille E, Kahn JG, Saba J. Cost-effectiveness of antiviral drug therapy to reduce mother-tochild HIV transmission in sub-Saharan Africa. AIDS. 1998;12:939-48.
3. Wilkinson D, Floyd K, Gilks CF. Antiretroviral drugs as a public health intervention for pregnant HIV-infected women in rural South Africa: an issue of cost-effectiveness and capacity. AIDS. 1998;12:1675-82.

4. Michael S, Steven G, Gloria S, Colin F, Donald B, Claudes K, et al. Cost-effectiveness of voluntary HIV-1 counselling and testing in re- ducing sexual transmission of HIV-1 in Kenya and Tanzania. Lancet. 2000;356:113-21.

5. Hunter S, Williamson J. Children on the brink 2000: updated estimates and recommendations for intervention. [Executive Summary]. Washington: USAID; 2000. Available from: http://www.usaid.gov/press/releases/ 2000/childrenreport.pdf. Accessed 28 February 2005. 
6. Sanders GD, Bayoumi AM, Sundaram V, Bilir SP, Neukermans CP, Rydzak CE, et al. Cost-effectiveness of screening for HIV in the era of highly active antiretroviral therapy. $\mathrm{N}$ Engl J Med. 2005 Feb 10;352(6):570-85.

7. Gibb DM, Ades AE, Gupta R, Sculpher MJ. Costs and benefits to the mother of antenatal HIV testing: estimates from simulation modelling. AIDS. 1999;13:1569-76.

8. Kumar A, St. White H, Carter AO. Trends in the uptake of antenatal voluntary counseling and testing for HIV and the HIV prevalence among childbearing women in Barbados, 1993-2004: evidence to gauge the effectiveness of HIV prevention measures. West Indian Med J. 2007;56(1):167-70.

9. Pan American Health Organization. Country profile-Barbados. PAHO. Available from: http://www.paho.org/English/DD/AIS/cp 052.htm. Accessed 17 January 2006.

10. Caribbean Epidemiology Centre; Pan American Health Organization/World Health Organization. Status and trends: analysis of the Caribbean HIV/AIDS epidemic 1982-2002. Port of Spain: CAREC; 2004.

11. St. John MA, Kumar A, Cave C. Reduction in perinatal transmission and mortality from human immunodeficiency virus after intervention with zidovudine. Pediatr Infect Dis J. 2003;22(5):422-6.
12. Kumar A, Vent B. Characteristics of HIV infected childbearing women in Barbados. Pan Am J Public Health. 2003 Jan;13(1):1-9.

13. Manzi M, Zachariah R, Teck R, Buhendwa L, Kazima J, Bakali E, et al. High acceptability of voluntary counselling and HIV-testing but unacceptable loss to follow up in a prevention of mother-to-child HIV transmission program in rural Malawi: scaling-up requires a different way of acting. Trop Med Int Health. 2005 Dec;10(12):1242-50.

14. Ickovics JR, Forsyth B, Ethier KA, Harris P, Rodin J. Delayed entry into health care for women with HIV disease. AIDS Patient Care STDS. 1996;10(1):21-4.

15. Segurado AC, Miranda SD, Latorre MD; Brazilian Enhancing Care Initiative Team. Evaluation of the care of women living with HIV/AIDS in Sao Paulo, Brazil. AIDS Patient Care STDS. 2003;17(2):85-93.

16. Paredes R, Mocroft A, Kirk O, Lazzarin A, Barton SE, van Lunzen J, et al. Predictors of virological success and ensuing failure in HIV-positive patients starting highly active antiretroviral therapy in Europe: results from the EuroSIDA study. Arch Intern Med. 2000; 160(8): 1123-32.

17. Palella FJ Jr, Deloria-Knoll M, Chmiel JS, Moorman AC, Wood KC, Greenberg AE, et al. HIV Outpatient Study Investigators. Survival bene- fit of initiating antiretroviral therapy in HIVinfected persons in different CD4+ cell strata. Ann Intern Med. 2003 Apr 15;138(8): 620-6.

18. Ormaasen V, Bruun JN, Sandvik L, HolbergPetersen M, Gaarder PI. Prognostic value of changes in CD4 count and HIV RNA during the first six months on highly active antiretroviral therapy in chronic human immunodeficiency virus infection. Scand J Infect Dis. 2003;35(6-7):383-8.

19. Hogg RS, Yip B, Chan KJ, Wood E, Craib KJ, O'Shaughnessy MV, et al. Rates of disease progression by baseline CD4 cell count and viral load after initiating triple-drug therapy. JAMA. 2001 Nov 28;286(20):2568-77.

20. Kumar A, Kilaru KR, Forde S, Kumari G. Prevalence and correlates of serostatus disclosure in HIV-infected adults attending the follow up and treatment clinic in Barbados. Social Medicine. 2007;2(2):89-97.

21. Kumar A, Waterman I, Kumari G. Prevalence and correlates of HIV serostatus disclosure: a prospective study among HIV-infected postparturient women in Barbados. AIDS Patient Care STDS. 2006;20(10):724-30.

Manuscript received on 17 July 2006. Revised version accepted for publication on 29 October 2007.
RESUMEN

Utilización de los servicios de atención sanitaria y estado de salud de las mujeres seropositivas al VIH diagnosticadas mediante el tamizaje prenatal para el VIH en Barbados, 1996-2004

Palabras clave
Objetivos. Estudiar la utilización de los servicios de atención sanitaria relacionados con el VIH y describir el estado de salud de las mujeres infectadas con este virus, diagnosticadas mediante el asesoramiento y la prueba de detección del VIH de carácter voluntario (APDV) durante el período prenatal en Barbados.

Métodos. Este es un estudio descriptivo. La población de estudio abarcó a todas las mujeres infectadas por el VIH, diagnosticadas en Barbados mediante el APDV en 1996-2004.

Resultados. La mediana de la duración de la infección por el VIH — desde el diagnóstico hasta el momento de este informe- en las 163 mujeres diagnosticadas durante el período de estudio fue de 72 meses (nivel bajo: 9 meses; nivel alto: 117 meses). De las 163 mujeres, $102(62,6 \%)$ asistieron a la clínica centralizada para el VIH/sida para su seguimiento (atención, tratamiento y monitoreo), mientras que $61(37,4 \%)$ nunca asistieron a la clínica. La mediana del lapso entre el diagnóstico de la infección por el VIH y la primera presentación a la clínica para el VIH/sida fue de 36 meses (nivel bajo: 1 mes; nivel alto: 114 meses). Más de la cuarta parte de las mujeres infectadas que acudieron a la clínica presentaban inmunodeficiencia grave en el momento de su primera consulta de seguimiento. De las 53 mujeres que se sometieron al tratamiento antirretroviral de gran actividad (HAART) durante el estudio, $23(43,4 \%)$ comenzaron el tratamiento en los tres meses siguientes a su primera visita de seguimiento.

Conclusiones. El diagnóstico temprano mediante el APDV no garantiza que las mujeres con VIH reciban una atención adecuada y oportuna para tratar esa infección. Estas mujeres sufren una mortalidad significativamente prematura, en gran parte debido al inadecuado seguimiento.

Infecciones por VIH, mujeres embarazadas, estado de salud, Barbados. 